\title{
Comment 2 on "Ultra-high pressure and ultra-reduced minerals in ophiolites may form by lightning strikes"
}

\author{
J.S. Yang ${ }^{1 *}$, R.B. Trumbull2, P.T. Robinson', F.H. Xiong1', D.Y. Lian ${ }^{3}$
}

\section{Comment}

Received 23 May 2018 | Accepted 3 August 2018 | Published 3 September 2018

We read with great interest the paper by C. Ballhaus and coauthors (2017) reporting on electrical discharge experiments that showed how $\mathrm{SiC}$ and other phases found in mantle-derived rocks can potentially form by lightning strikes (Ballhaus et al., 2017). The experiments are technically innovative and challenging and the results make fascinating reading. In a comment paper, Griffin et al. (2018) noted several lines of evidence that ultra-high pressure (UHP) and super reduced (SuR) minerals in ophiolites do not form by lightning strikes. Here, we add additional comments relating to the geological and mineralogical data from ophiolites that are not compatible with the model of Ballhaus et al. (2017).

(1) Not all of the samples of podiform chromitite and peridotite hosting UHP and SuR minerals were collected from surface outcrops exposed to lightning; many come from active mines 30-50 m below the surface, from the interiors of large blocks of ore, and/or from deep drill cores (Zhang et al., 2016, 2017). Fulgurites are near-surface features, typically consisting of highly shattered and brecciated rock, which rarely extend more than a few meters below the surface. Furthermore, many of the same UHP and SuR minerals are routinely found in kimberlites sampled by deep mining operations (Shiryaev et al. 2011) leaving no question of their presence in the deeper mantle.

(2) Although lightning strikes can produce SuR minerals such as silicon carbide (moissanite), native metals and metal silicides (e.g., Essene and Fisher, 1986; Rodgers et al., 1989; Sheffer et al., 2003), no UHP minerals have been reported from fulgurites; yet both moissanite and diamond grains occur together in ophiolite samples (Yang et al., 2014, 2015a; Zhang et al., 2016). These grains are mostly 200-300 $\mu \mathrm{m}$ in size and typically have euhedral to subhedral morphologies, whereas the experiments by Ballhaus et al. (2017) produced SiC crystals 100 times smaller, all of which are anhedral. In-situ diamonds in ophiolites are typically well-formed crystals enclosed in small $(1 \mathrm{~mm})$ spheres of amorphous carbon.

(3) No solid inclusions were reported from the minerals produced in Ballhaus' experiments, nor have mineral inclusions been reported in any known fulgurite phases. In contrast, diamonds in ophiolites contain a wide range of UHP and SuR mineral inclusions, including $\mathrm{SiC}, \mathrm{NiMnCo}$ and other alloys, Mn-silicates (olivine, garnet), Mn-oxides, chromite and coesite; some even have fluid inclusions (Yang et al., 2015a; Moe et al., 2018; Wu et al., 2017). These features are inconsistent with instantaneous shock metamorphism. Besides, there are well-documented exsolution lamellae of coesite and clinopyroxene in some chromite grains that require a high-pressure residence of $\mathrm{SiO}_{2}$ in the grains (Yamamoto et al., 2009), and this phenomenon should not be observed in fulgurite either.

(4) Barren, high-elevation terranes such as those in Tibet might be ideal locations for abundant lightning strikes, as suggested by Ballhaus et al. (2017), but there is nothing unique about the UHP and SuR occurrences in Tibet. These minerals have been confirmed in more than 10 different ophiolites in China, India, Russia, Myanmar, Albania, and Turkey, areas with different elevations and different climates (Yang et al., 2015b; Das et al., 2017; Lian et al., 2017; Wu et al., 2017).

The discovery of UHP and SuR minerals in rocks from the oceanic mantle has led to a variety of models for their formation (Arai et al., 2013; Zhou et al., 2014; Robinson et al., 2015; Griffin et al., 2016; Rollinson, 2016; Ballhaus et al., 2017; Butler and Beaumont, 2017), none of which fully explain these occurrences. We emphasise that the presence of UHP and SuR phases in ophiolites is difficult to reconcile with the overwhelming geologic evidence that the host bodies form in the upper mantle. What now seems clear to us is that many ophiolites are bodies, which had a complex history involving subduction of crustal material at least to the transition zone, mixing of such material with mantle peridotites, partial melting and recrystallisation followed by upward migration to shallow levels where mantle slabs were trapped in suprasubduction zone wedges and modified by reaction with fluids and melts. The result is a mixture of crustal and mantle material which appears to exist metastably in ophiolitic chromitites and peridotites. Therefore, we do not consider lightning strikes to be an important source of UHP and SuR minerals in ophiolites, but the geologic processes leading to their formation are still poorly understood.

\section{Acknowledgements}

This study was supported by the NSFC (No. 41720104009) and the CGS (No. DD20160023-01) and MLR (201511022).

\footnotetext{
1. CARMA, Key Laboratory of Deep Earth Dynamics of MNR, Institute of Geology, Chinese Academy of Geological Sciences, Beijing, 100037, China

2. GFZ German Research Centre for Geosciences, Telegrafenberg, Potsdam, 14473, Germany

3. School of Earth Sciences and Engineering, Nanjing University, Nanjing, 210023, China

Corresponding author (email: yangjsui@163.com)
} 


\section{Additional Information}

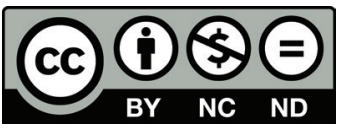

This work is distributed under the Creative Commons Attribution Non-Commercial No-Derivatives 4.0 License, which permits unrestricted distribution provided the original author and source are credited. The material may not be adapted (remixed, transformed or built upon) or used for commercial purposes without written permission from the author. Additional information is available at http://www.geochemicalperspectivesletters.org/ copyright-and-permissions.

Cite this letter as: Yang, J.C., Trumbull, R.B., Robinson, P.T., Xiong, F.H., Lian, D.Y. (2018) Comment 2 on "Ultra-high pressure and ultra-reduced minerals in ophiolites may form by lightning strikes". Geochem. Persp. Let. 8, 6-7.

\section{References}

ARAI, S. (2013) Conversion of low-pressure chromitites to ultrahigh-pressure chromitites by deep recycling: a good inference. Earth and Planetary Science Letters 379, 81-87.

Ballhaus, C., Wirth, R., Fonseca, R.O.C., Blanchard, H., Pröll, W., Bragagni, A., Nagel, T., Schreiber, A., Dittrich, S., Thome, V., Hezel, D.C., Below, R., CieszynsKI, H. (2017) Ultra-high pressure and ultra-reduced minerals in ophiolites may form by lightning strikes. Geochemical Perspectives Letters 5, 42-46.

Butler, J.P., BeAumont, C. (2017) Subduction zone decoupling/retreat modeling explains south Tibet (Xigaze) and other supra-subduction zone ophiolites and their UHP mineral phases. Earth and Planetary Science Letters 463, 101-117.

Das, S., BASU, A.R., MUKHERJEe, B.K. (2017) In situ peridotitic diamond in Indus ophiolite sourced from hydrocarbon fluids in the mantle transition zone. Geology 45, 755-758.

EsSENE, E.J., FISHER, D.C. (1986) Lightning strike fusion: extreme reduction and metal-silicate liquid immiscibility. Science 234, 189-193.

Griffin, W.L., Afonso, J.C., Belousova, E.A., Gain, S.E., Gong, X.H., Gonzalez-Jimenez, J.M., Howell, D., Huang, J.X., McGowan, N., Pearson, N.J., Satsukawa, T., Shi, R., Williams, P., Xiong, Q., YANG, J.S., ZHANG, M., O'REILlY, S.Y. (2016) Mantle recycling: transition zone metamorphism of Tibetan ophiolitic peridotites and its tectonic implications. Journal of Petrology 57, 655-684.

Griffin, W.L., Howell, D., Gonzalez-Jimenez, J.M., XIONG, Q., O'ReILly, S.Y. (2018) Comment on "Ultra-high pressure and ultra-reduced minerals in ophiolites may form by lightning strikes". Geochemical Perspectives Letters 7, 1-2.

Lian, D., YAnG, J., Dilek, Y., WU, W., Zhang, Z., XiOng, F., LiU, F., ZHOU, W. (2017) Deep mantle origin and ultra-reducing conditions in podiform chromitite: Diamond, moissanite, and other unusual minerals in podiform chromitites from the Pozanti-Karsanti ophiolite, southern Turkey. American Mineralogist 102, 1101-1113.

Moe, K.S., YAnG, J.S., Johnson, P., XU, X., WAnG, W. (2018) Spectroscopic analysis of microdiamonds in ophiolitic chromitite and peridotite. Lithosphere 10, 133-141.

Robinson, P.T., Trumbull, R.B., Schmitt, A., Yang, J.S., Li, J.W., ZHOU, M.F., ERZINGER, J., DARE, S., XIONG, F. (2015) The origin and significance of crustal minerals in ophiolitic chromitites and peridotites. Gondwana Research 27, 486-506.

Rodgers, K.A., Courtney, S.R, Seelye, R., Mcculloch, B.A., MulHolLAND, I. (1989) An occurrence of "moissanite" (SiC) from Seddonville, West Coast, New Zealand. New Zealand Natural Sciences 16: 105-108.

Rollinson, H., (2016) Surprises from the top of the mantle transition zone. Geology Today 32, 58-64.

Sheffer A.A., Melosh, H.J., Jarnot, B.M., Lauretta, D.S. (2003) Reduction of silicates at high temperature: fulgurites and thermodynamic modeling. 34th Annual Lunar and Planetary Science Conference, March 17-21, 2003, League City, Texas. Abstract no. 1467.

Shiryaev, A.A., Griffin, W.L., Stoyanov, E. (2011) Moissanite (SiC) from kimberlites: Polytypes, trace elements, inclusions and speculations on origin. Lithos 122, 152-164.
Wu, W.W., Yang, J.S., Ma, C.Q., Milushi, I., Lian, D.Y., Tian, Y.Z. (2017) Discovery and Significance of Diamonds and Moissanites in Chromite within the Skenderbeu Massif of the Mirdita Zone Ophiolite, West Albania. Acta Geologica Sinica (English Edition) 91, 882-897.

Yamamoto, S., Komiya, T., Hirose, K., Maruyama, S. (2009) Coesite and clinopyroxene exsolution lamellae in chromites: In-situ ultrahigh-pressure evidence from podiform chromitites in the Luobusa ophiolite, southern Tibet. Lithos 109, 314-322.

YANG, J.S., Robinson, P.T., DiLEK, Y. (2014) Diamonds in ophiolites. Elements $10,127-130$

Yang, J.S., Meng, F., Xu, X., Robinson, P.T., Dilek, Y., MakeyeV, A. B., Wirth, R., Wiedenbeck, M., Cliff, J. (2015a) Diamonds, native elements and metal alloys from chromitites of the Ray-Iz ophiolite of the Polar Urals. Gondwana Research 27, 459-485.

YAnG, J.S., Robinson, P.T., DileK, Y. (2015b) Diamond-bearing ophiolites and their geological occurrence. Episodes 38, 344-364.

ZhANG, R.Y., YANG, J.S., ERnst, W.G., JAHN, B.M., IIZUKA, Y., GuO, G.L. (2016) Discovery of in situ super-reducing, ultrahigh-pressure phases in the Luobusa ophiolitic chromitites, Tibet: New insights into the deep upper mantle and mantle transition zone. American Mineralogist 101, 1245-1251.

ZhanG, R.Y., Shau, Y.H., YAnG, J.S., LiOU, J.G. (2017) Discovery of clinoenstatite in the Luobusa ophiolitic mantle peridotite recovered from a drill hole, Tibet. Journal of Asian Earth Sciences 145, 605-612.

Zhou, M.F., Robinson, P.T., Su, B.X., GaO, J.F., Li, J.W., YanG, J.S., MALPAS, J. (2014) Compositions of chromite, associated minerals, and parental magmas of podiform chromite deposits: The role of slab contamination of asthenospheric melts in suprasubduction zone environments. Gondwana Research 26, 262-283. 